\title{
Embracing Transculturalism and Footnoting Islam in Accounts of Arab Migration to Cuba
}

\author{
Elena Fiddian-Qasmiyeh \\ University College London, UK
}

\begin{abstract}
This article traces the development of Cuban analyses of Arab migration to the island from the 1500 s to the present. It asks whether there is a specifically "Cuban" school of "migration studies, " analysing the nature and implications of Ortiz's concept of transculturation underpinning the post-colonial development of "Cuban national identity." It further argues that, despite official Cuban claims regarding post-revolutionary racial equality, Arab migration has not only been historically and politically marginalised in accounts of the development of "Cuban identity", including in Ortiz's own work, but diverse "waves" of Arab migration to the island have been characterised by what I refer to as the accumulative "footnoting of Islam." In conclusion, I argue that Muslim Arab immigration prior to the Cuban Revolution has been entirely overshadowed by a systematic focus on Christian Arabs, in effect leading to the category “Arab” being practically synonymous with "Christian” or "Maronite”, with wide-ranging implications for our understanding of Cuba's academic and political discourses regarding national identity in the twentieth and twenty-first centuries.
\end{abstract}

Keywords: Ortiz, Muslims, national identity, religion, transculturation 


\section{Introduction}

Since the 1980s, the Cuban population's "Arab component" has been documented by key Cuban institutions, including the Oficina del Historiador de la Ciudad de la Habana (Office of the Historian of the City of Havana), the anthropological Fundación Fernando Ortiz (henceforth 'Fundación'), and the Unión Árabe de Cuba ("Cuba's Arab Union”). Such Cuban studies of immigration systematically assert that one thousand "Arabs" were living in Cuba by 1898 , celebrating many of these Arab-Cubans' roles as revolutionary soldiers (mambises) in the 1895 War of Independence (González 1997; Grillo-Candales n.d) and later in Castro's Revolution (Nejme-Franco n.d.). These studies equally celebrate Arab migrants' success in "assimilating" and "integrating" within Cuban society, consistently asserting that Arab immigration to Cuba offers “a good example of integration" (González 2003), ${ }^{1}$ or, more resolutely declaring that, "of all immigration [to Cuba], Arab immigrants were the fastest and best in assimilating and integrating to our socio-cultural environment” (Perdomo-Lorenzo 1992, n.p.). Cuban authors typically continue by stating that these Arab immigrants' estimated 50,000 "descendents are, today, practically indistinguishable from the rest of the Cuban population" (Sánchez-Porro 1994: n.p), and that they share the political goal of promoting a strong and unified Cuban national identity (González 1997).

This approach to Arab immigration parallels broader studies conducted by the Fundación, various Cuban Research Centres including the Centro de Estudios de Africa y el Medio Oriente and Departments at the University of Havana, and the state's Oficina del Historiador, which aim to demonstrate the assimilation, integration and wholehearted incorporation of these migrant communities into Cuban "national identity." With specific reference to Arab immigration, however, they all make, perpetuate and solidify one major assumption: that Arab immigration to Cuba was a Christian phenomenon, with the vast majority of Arab migrants arriving in Cuba belonging to Maronite Christian families from the Levant.

Although it is at times recognised, en passant, that "Arab immigration to Cuba was multiethnic, multinational and multiconfessional in nature" (Menéndez-Paredes 1998, 54), and that a not insignificant proportion of Arab immigrants were Muslim, all academic and institutional studies to date focus on Christian immigration to Cuba, rather than exploring or contextualising Arab Muslim immigration to the island (i.e. Menéndez-Paredes 2001, esp. 30). This article therefore asks why the historical and contemporary presence and experience of Muslim Arabs in Cuba has, to all extents and purposes, been marginalised in studies of the island, despite traces of their 
existence being readily identifiable to interested observers. Indeed, the absence of such analyses is particularly notable given that extensive research exists on the multiple trajectories and roles of Muslim Arabs across Central and South America (i.e. Klich and Lesser's edited collection [1998]; Jozami 1996; Civantos 2006), and, as Gómez notes vis-a-vis the invisibility of Muslim Africans (as opposed to Muslim Arabs) in accounts of migration to Cuba, "it is logical to assume that Muslims were arriving in Cuba in proportions similar to those in Mexico. That Cuba never developed a reputation as a Muslim haven requires some explanation..." $(2005,33)$.

While I do not contest Menéndez-Paredes' assertion that Christian Maronites were, and continue to be, the most important religious group of the Arab diaspora in Cuba and across the American continent (1999; also Suleiman [1995, 67-85]), this article critiques official Cuban anthropological analyses of Arab migration to Cuba which have embraced Christian Arab migrants as part of the Cuban Self, whilst displacing the Muslim Arab (as the) Other. I situate this discussion within a broader analysis of twentieth century accounts of diverse migrant communities' arrival in Cuba and their contribution to Cuba's hybrid national-identity. Contrasting the multifaceted and longstanding marginalisation of Muslim Arabs with the wealth of Cuban studies and political conmemorations of the contributions of Other migrant communities (in particular Chinese and Jewish immigrants to Cuba), I explore how, why and to what effect such studies of migration are implicated in the broader politics of Cuban national identity; in particular, I highlight that long-standing racial and religious hierarchies challenge Cuba's official policy of egalitarianism and racial equality.

The article therefore firstly explores how Cuban socio-anthropological analyses of Arab migration have developed, whether there is a specifically "Cuban" school of "migration studies", and how migration, ethnicity and religion are related to the development of Cuba's official national identity. Secondly, it documents various "waves" of Arab migration to the island, arguing that these have been characterised by the accumulative concealment of Islam. Thirdly, it provides a preliminary comparative analysis of accounts of Muslim Arab, Chinese and Jewish migration to Cuba, asking why certain migrant communities, such as Chinese and Jewish migrants, have been the focus of academic and national/political attention while Muslim Arabs have effectively been rendered invisible.

\section{Methodological Reflection}

This article draws on insights developed and materials analysed during a three-month fieldwork visit to Cuba in 2006. While I had originally arrived in Cuba intending to explore the experiences 
and expectations of Sahrawi refugee youth participating in Cuba's internationalist scholarship programme (Fiddian-Qasmiyeh 2014), I soon developed a parallel project comparing Sahrawi refugees' experiences with those of other Muslim Arab students studying in the island (FiddianQasmiyeh, 2010, 2015). Examining the experiences of Sahrawi, Palestinian, Yemeni and Syrian students in Cuba as Muslims, and developing an analysis of the history of Cuba's scholarship programme for citizens and refugees from across the Middle East and North Africa (MENA) since the 1960s, led me to argue "that the presence of Muslim Arab youth in Cuba today can be understood as constituting a new form of migration - educational migration - that supersedes previous forms of connections between the Middle East and Cuba" (ibid, 139). This article therefore complements my earlier research on the presence of Muslim Arab students in Cuba following the Cuban Revolution, to analyse the broader history of Arab Muslims' presence in Cuba from the 1500s to the present, and the nature of Cuban accounts of Arab migration to the island.

During my fieldwork in Havana I interviewed twenty MENA Muslim university students about their experiences in Cuba, the internationalist scholarship programme, and their perceptions of Cuba's historical connections to the MENA region, including Arab migration to Cuba. These interviews were complemented with informal interviews with four Cuban converts to Islam, and over a dozen Cuban academics specialised in different phases of "Arab" immigration to Cuba. Participant observation and archival research were completed in Cuban institutions which focus on "Arabs in Cuba" and "Arab migration," such as the Union Árabe de Cuba, the Casa de los Árabes, and the Fundación Fernando Ortiz, with extensive materials located in the Centro de Estudios de África y el Medio Oriente, in the Oficina del Historiador, in the Biblioteca Nacional and in Cuba's national archives. The Fundación was my research base, and I benefitted from regular interviews with and access to publications by members of the Fundación, which has been pivotal in developing Cuban analyses of the role of migrant groups as "components" of "Cuban national identity."

Given my focus on Muslim Arab students' experiences as Muslims in contemporary Havana, I became increasingly aware of the invisibility of Islam in mainstream Cuban accounts of Arab migration to Cuba, leading to the current analysis, which counterbalances the hypervisibility of certain migrants in the official development and reinforcement of Cuban national identity, with the effective erasure of Muslim Arabs throughout different historical periods. The article's broadly deconstructive framework, and in particular the decision to centralize that which has 
previously been assigned a peripheral position, therefore developed following my departure from Cuba, as I re-analysed interview transcripts, archival materials and broader literature on the history and present of Arabs in Cuba.

\section{Cuban analyses of immigration: Hybridisation, transculturation and repress-entation}

Since the 1990s, Cuban academic and national institutions have traced the histories of different immigrant groups in Cuba. The Fundación has played a central role publishing analyses of “African," "Chinese," “Arab," "Japanese," "Hebrew," "Canary", "French" and "German" migration to Cuba, documenting how these and other migrant communities became integral components of "Cuban national identity." The Fundación's role as the key Cuban academic institution producing and disseminating anthropological "knowledge" about histories of immigration in/to Cuba cannot be underestimated, and builds directly upon the legacy of Fernando Ortiz (1881-1969), the Spanish-Cuban anthropologist after whom the Fundación is named. Indeed, two of Ortiz's interrelated, if at times contradictory, legacies are of particular relevance to my analysis.

Firstly, one of Ortiz's most significant anti-colonial political contributions in the early- $20^{\text {th }}$ Century was to centralise hybridity in conceptualisations of Cuban national identity, simultaneously rejecting the prevailing assumption that Cuban culture was born of Spanish colonial roots, and, for the first time, recognising the contribution of "Africans" to Cuba's identity for the first time. Ortiz's theory of "transculturation" became a key foundation of postRevolutionary official discourses of Cuban identity and belonging. Consciously developed "as a substitute for the term acculturation" (Ortiz, [1940] 1995, 97) which had been pro/imposed by Western sociologists and anthropologists, Ortiz argued in his 1940 study Contrapunteo cubano del tabaco y el azucar that the neologism "transculturation"

better expresses the different phases of the process of transition from one culture to another because this does not consist merely in acquiring another culture, which is what the English word acculturation really implies, but the process also necessarily involves the loss or uprooting of a previous culture, which could be defined as a deculturation. In addition it carries the idea of the consequent creation of a new cultural phenomena, which could be called neoculturation. (102-103)

More concretely, Ortiz asserted that "the real history of Cuba is the history of its intermeshed transculturations" (98), "an intense, complex, unbroken process of transculturation of human groups, all in a state of transition" (103). Centralising the multiple flows of diverse "human 
groups" to the island, he held that "there were no more important human factors for Cubanity [para la cubanidad] than these continuous, radical and contrasting geographical, economic and social transmigrations...” (1963, 102, author's translation).

Through the metaphor of the ajiaco, an intense Cuban stew prepared with leftover ingredients, Ortiz identified diverse "human groups" as the ingredients which together form an ever-evolving multi-racial, hybrid Cubanity, arguing that

Cubanidad is not solely to be found in the [stew], but also in the complex process of its very formation, [which is both] disintegrative and integrative... being ajiaco, [the Cuban nation] is not a prepared stew, but is rather a constant process of cooking... It is for this reason that its composition changes and that Cubanidad should have different flavours and consistencies depending on whether one tastes [the stew] from the bottom, from the pot's belly, or from [its surface]. (Ortiz [1939]1993, 6-7, author's translation)

Cuban national identity is thus conceptualised as inherently multi-racial and "constantly inbecoming"'2 as a result of multidirectional transculturation:

Throughout a century of commotions, heterogenous elements were united, merged and re-merged into a common Cuban consciousness. However, the nation is not yet made, nor is its mass integrated. Even today, uninterupted exogenous flows continue to arrive, flows of white, black and yellow immigrants, of interests and of ideas, stirring and dissolving into the Cuban broth, deferring the consolidation of a definitive and basic national homogeneity. (20)

Indeed, Ortiz's second major contribution is his detailed documentation of the "human groups" he identified as playing a pivotal role in the development of Cuba's hybrid national identity through this continuous process of transculturation.

In a 1939 presentation published in 1940 under the title Los factores humanos de la cubanidad, Ortiz poses the question "Which are the human elements which are merged with Cuban life to produce Cubanidad?" (1991, 8, author's translation), subsequently identifying “four great vulgar races":

It appears simple to classify the human elements combined in Cuba by their races: copper Indians, white Europeans, black Africans, and yellow Asians. The four great vulgar races have embraced, mixed and re-mixed in our land over generations.

Indeed, despite resisting imperialist discourses and vocally denouncing classificatory systems "as absurd and artificial as the imaginary races invented by the race theorists of the present" ([1940] 
1995, 23), Ortiz's conceptualisations of race and cultural groups both throughout his positivistinspired criminological research (1910s-1920s) and his subsequent 'turn' to transculturalism in the 1930s and 1940s, reflect the continued influence of these very frameworks. Hence, a major tension exists in Ortiz's work between centralising the ongoing transculturation of multiple migratory flows underpinning a hybrid Cubanidad, and the consistent return to colonial racial typologies.

On the one hand, therefore, in Contrapunteo Ortiz refers to the interactions of Cuba's autochtonous inhabitants ("paleolithic Indian"), Spanish colonialists and immigrants, the "steady stream of African negroes" and "other immigrant cultures" including "Indians from the mainland, Jews, Portuguese, Anglo-Saxons, French, North Americans, even yellow Mongoloids from Macao, Canton, and other regions of the sometime Celestial Kingdom" (Ortiz 1995:9). In the same text, he further identifies that "in the first waves of immigration came Genoese, Florentines, Jews, Levantines, and Berbers... - that is to say, representatives of the Mediterranean culture" (100), and that "after the Negroes began the influx of Jews, French, Anglo-Saxons, Chinese, and peoples from the four quarters of the globe" (102).

On the other hand, despite highlighting the presence and incorporation of these diverse peoples into Cuba's ajiaco, Ortiz notes that his ongoing research in the 1940s will deal "with the effects on Cuba of the transculturations of Indians, whites [sic], Negroes, and Mongols" (1995, 103, emphasis added), ${ }^{3}$ demonstrating a direct continuation with his positivist conceptualisation of ethnicity throughout the 1910s, in which his research focused on "representatives of the four classical ethnic types: white (Europeans and their descendants), black (Africans), yellow (Chinese), and copper (the Yucatecs)" ([1913]1986, 86, author's translation). A further continuity with colonial conceptualisations of race emerges in Ortiz's hierarchy of most and least influencial races in the development of Cuban national identity: he clearly asserts the primary role of the white race (identified as the "basic" race), the secondary influence of the black race, and only a marginal influence of the "Asiatic races" (ie. ibid; also 1939, 19).

Indeed, whilst "groundbreaking... Ortiz's work was not revolutionary" (Davies 2000,142), and his political and academic legacy is equally paradoxical at times. Most importantly, Ortiz's conceptualisations of both the hybrid sense and consciousness of self referred to by Ortiz as Cubanidad y Cubanía ("Cubanness and Cubanity," 1964), and of the racial composition of mestizo Cuban national identity, were directly embraced by the 1959 Cuban Revolution which 
officially identified and celebrated the four main components of post-colonial Cuban identity as “Indian”, "Spanish”, “African” and "Chinese” (López 2009, 195). Ortiz’s typologies and the classification of certain groups' greater or lesser influence on the Cuban nation have been further reinscribed through academic work produced inside and outside of Cuba throughout the 1990s and 2000s, much of which directly traces its origins to Ortiz's work (ie Guanche, 2005).

Essentially, the reinscription, legitimation and celebration of specific racial components and certain modes of cultural and racial hybridity, following Ortiz, have necessarily been accompanied by processes of racial and cultural, but also religious, marginalisation and exclusion. It is this system of centralising and heralding certain groups of migrants and particular identity markers whilst concealing others, in this case religious markers, which I refer to in this article and elsewhere as a mode of repress-entation (Fiddian-Qasmiyeh 2010, 2014). Such processes of exclusion and concealment are evidently multiple, and yet I argue in the remainder of this article that particular groups have more readily been "quietly dropped out of sight," a process systematically identified by Almond in his critique of the Orientalist foundations of key postmodern thinkers ranging from Hegel to Baudrillard to Žižek $(2007,180) .{ }^{4}$

On the one hand, this correlates with Scherer's denunciation, in the context of studies of Chinese immigration to Cuba, that 'the disproportionate obsession with Afro-Cuban 'cults,' shown by historians, sociologists and anthropologists alike, has left little space for the exploration of 'Chinese religion' in Cuba" $(1998,9)$. Indeed, far from the Martian myth of racial democracy in post-Revolutionary Cuba and the official denomination of racial discrimination as "unpatriotic due to the founding nationalist mythology of racial harmony" (Roland 2006, 152), an expanding literature on racial politics in contemporary Cuba identifies and critiques institutionalised and popular forms of discrimination and racism against diverse groups (ibid; de la Fuente 2001). Hence, it has been widely noted that "The study of racial politics in Post-Soviet Cuba has been overwhelmingly framed within a black-white binary," and that "for the most part... studies on race relations and racial politics of Cubans of color in contemporary Cuba have neglected the existence of Chinese-Cubans and their role within Cuban race relations and politics" (Ju 2014). Importantly, it is possible to trace a parallel with Ortiz's work in the relative displacement of Chinese-Cubans in contrast with the overarching contemporary focus on the "black-white binary": as noted above, Ortiz denominated the "Asian" influence on Cuban national identity as being of "tertiary" importance, regularly asserting that "the Cuban ethnic factor can be reduced solely to two extremes: white and blacks" (los factores... :16, author's translation), with his 
particular focus on "the Cuban integration of blacks and whites" continuing into the 1940s ([1942] 1993, 141-143).

Nevertheless, despite evidence supporting such denunciations, the Chinese "component" of Cuban identity has been nationally celebrated since before the Revolution, and a significant amount of research has been conducted on Chinese-Cuban migration and identities by Cuban and non-Cuban analysts alike. In particular, studies have traced the importation of those referred to by Ortiz as "semi-slave Chinese" $(1995,85)$ who substituted African slave labour following the abolitionist movements of the 1800s, focusing on the exploitation, violence and high mortality rates amongst Chinese labourers, and on the extent to which "Many [Chinese labourers] reacted [to the harsh conditions] by running away to join the independence struggle [the War of Independence]", noting that "as a reward, the rebel parliament promised them liberty and citizenship" (Benton 2010, 160). Article 29(d) of the 1940 Cuban Constitution, granting Cuban citizenship to all foreigners who had fought in the Liberation Army for over a year, built upon the rebels' commitment to "[champion] the idea of a 'raceless nation', democratic and inclusive, and [validate] the Chinese role in Cuban national identity" (164). Whilst simultaneously being considered "by other Cubans to be both essential to Cuban national identity and 'exotic' at the same time" (Ju 2010, referencing López 2004), their involvement was ultimately "celebrated in a monument to the Chinese role in the independence struggle unveiled in Havana in 1946..." (167), and has subsequently been documented in detail by academics and politicians alike.

On the other hand, while it is now broadly recognised that particular "human groups" identified by Ortiz have been centralised in the Cuban nation-building project to the relative detriment of others, so too have these particular groups been either implicitly or explicitly associated by Ortiz and his followers with particular religious identities and practices. In effect, Ortiz's analyses of religion typically associate "white" migratory flows with introducing diverse forms of Christianity to Cuba (including in particular Catholicism, but also Presbyterian Protestantism, Methodist or Baptist beliefs, Ortiz 1939,15) while "black" African transmigrations are associated with fetishism, especially amongst the Lucumi. In turn, Ortiz's references to the religionmigration nexus also explicitly recognise the surrepticious arrival of "Jews and Judaists" (1939,18-19) through subtle means given that "the Jewish culture has always tended to be hidden amongst that of other groups, to avoid persecution" (ibid), "infiltrating" Cuba via Portuguese, Flemish, Italian, British, French, even German and later North American and Polish migrant flows. 
With 18 lines dedicated to the arrival of Judaism and Jews to Cuba in a 20 page analysis entitled "Los factores humanos de la cubanidad" (1939,1-20), it is notable that Ortiz offered no such explicit attention to the arrival of Muslim Arab migrants to the island. Furthermore, those who have developed analyses of migration to Cuba since Ortiz's death have reproduced this absence. As such, while analyses of 'Religion in the Work of Fernando Ortiz' (the title of Ramírez-Calzadilla's 2005 chapter) note that Ortiz recognised that the Spanish Catholicism which was imported to the island was historically "influenced by Jewish, Moorish and Medieval superstitutions" (2005, 194, emphasis added), and Ramírez-Calzadilla's confirms that "Jewish immigrants brought their religion through various organizations and synagogues" and that "other philosophical religious forms, such as Baha'ism and theosophy, are also currently practiced and studied" in Cuba (ibid, 196, emphasis added), neither Ortiz nor subsequent analyses have comprehensively explored the presence or legacy of Arab Muslims in Cuba.

Nonetheless, Ortiz did at times implicitly infer the influence of Islam amongst the practices and belief systems of a range of "African" populations whose religious systems he typically characterised as " "underworld witchcraft' informing criminal activity" (Gomez 2005, 36). In particular, Ortiz "attempt[ed] to identify Islamic influence among the Lucumi” (36) but more broadly noted that:

The Islamic religion left indelible marks upon the theology of the blacks from the African regions... Plenty of Muslim slaves (mandingas, tolofes, fulas macuás, etc) entered Cuba, and those who probably referred to the god Olorun as Alá were from the Yorubas.

Ortiz, cited in ibid

Indeed, in his 2005 study subtitled The experience and legacy of African Muslims in the Americas, Gomez refers to the "problematic scholarship of Fernando Ortiz" as he attempts to discern the presence of African (as opposed to Arab) Muslims and "potential Muslims" in Cuba from the sixteenth-century onwards through a re-reading of Cuba's archives. Nonetheless, while Gomez ultimately agrees with Ortiz's "inferential" evidence that "It is inconceivable that the Mande, Fulbe and Wolof in Cuba did not include Muslims" given their origin from West Africa and the significance of Islamic reform in the region (ibid), neither Ortiz nor Gomez (or, indeed, others) have explicitly addressed the arrival of Muslim Arabs from North Africa or the Middle East, depite Ortiz's passing references to Levantine and Amazigh (ie 'Berber') migrants to Cuba (op cit).

As such, if Scherer regrets the "little space" which has been left for the exploration of the experiences and roles of Chinese-Cubans in general and Chinese religion in Cuba in particular 
(which Scherer largely equates with Confucianism despite Al-Ahari $[1999,447]$ proposing that by 1959 the majority of Muslims in Cuba were Chinese Muslims), I argue that Ortiz and his successors at the eponymous Fundación have produced works in which Muslim Arab migration in particular, and Islam in general is pushed "out of the centre of their texts and into the margins/footnotes/backdrop of their work" (Almond 2007, 183).

I therefore posit that in publications and analyses of Arab migration to Cuba including and following Ortiz's analyses, "Islam is excised because, quite simply, it had no place in the book[s] to begin with" (177), and that the marginalisation of the role of Muslim Arabs and Islam by Cuban intellectuals before and after the Revolution is paralleled and underpinned by the exclusion of Muslim Arabs from the Cuban nation-building project. The deconstructive framework espoused in this article therefore leads me to purposefully centralize that which has previously been assigned a peripheral position throughout the extensive "archive of knowledge" (Foucault 1989, 25) on Arabs in Cuba. This, in turn, leads us to ask whether there is a place for Islam and Muslims in contemporary Cuban academia and political projects alike.

Equally, just as Chinese-Cuban focused analyses consider that the erasure of Chinese immigrants from historical accounts "promoted, somewhat ambiguously, by the Cuban state and its intelligentsia" must be viewed as part of an Orientalist framework (Scherer 1998, 1), so too can the systems of repress-entation which have magnified the role played by Christian Arab migration, whilst footnoting the history and present of Muslim Arabs in the island. Consequently, we can therefore value Scherer's insight (9) that Cuban analysts'

descriptions of essential incomprehension and radical Otherness coincide with the Eurocentricity of many nineteenth-century Spanish and Cuban writers. The reason, then, why these descriptions are so biased resides in the Eurocentric and "Christian" perspectives of observers who had obviously great difficulty in conceiving of religion in non-Christian terms.

As such, just as Ortiz resisted imperialist discourses and denounced colonial racial typologies whilst his work embodied a clear tension between his conceptualisation of the ongoing transculturation of a truly hybrid Cubanidad and his consistent return to and reification of colonial classificatory systems, this tension has continued to be reproduced in academic and political rhetoric in the post-revolutionary era: official declarations of egalitarian, hybrid Cuban social and national structures are critiqued by Cuban and non-Cuban academics as prioritising the 'blackwhite binary' and 'obsession' with Afro-Cuban 'cults' evidenced in much of Ortiz's work. ${ }^{5}$ 
Complementing this critique of the continuity of racial and ethnic hierarchies, this article highlights the continuity of religious prejudices from the colonial past, with particular reference to Arab Muslim migration to the island. This raises a broader question of whether there is a "unique" postcolonial Cuban approach to Arab immigration, as argued by Ortiz and his followers, or whether Cuban repress-entations of such histories of migration validate and embody a Cuban inheritance of Eurocentric and Orientalist legacies.

\section{Repress-enting Arab Immigration to Cuba}

Despite adhering to Ortiz's political commitment to identify and celebrate the hybrid foundations of a united Cuban national identity through tracing the histories of immigrant groups' "transculturation" in the island, contemporary analyses completed by the Fundación and its associates consistently reassert, rather than challenge, certain elements of unilinear acculturation models of migrants' incorporation into their host society, and the prioritisation of particular migrant groups' contributions to Cuba's society and nation. In addition, or perhaps as a precondition, to celebrating Arab immigration to Cuba through terms such as "assimilation" and "integration," these studies invariably declare that, unlike the Jewish or Chinese communities which reportedly demonstrated "traditional" isolatory tendencies (Charon 1992, 35), the Arab "community assimilated itself immediately and came to have from the first moment, cordial relations and work contact with Cuban nationals" (González 1997, 9); Charon ultimately declares that Arab immigration to Cuba has been considered to be one of "the most assimilatable" of all immigrant groups which arrived in Cuba $(1992,56)$.

It is perhaps this successful "assimilation" of Arab immigrants into the Cuban nation which has led to numerous authors excluding Arabs entirely from overviews of immigration to Cuba, thereby consolidating their invisibility. However, several accounts from the early-1900s use disparaging terms to refer to Arabs in general and Muslims more specifically, revealing their presence in Cuba through the authors' invocations of Orientalist tropes:

The Turks, as a group, are fanatics, like Muslims in general, and it is therefore not advisable to allow them to form large colonies... The Syrians, ${ }^{6}$ whilst being Ottoman subjects, also [sic] have a greater tendency to Europeanise themselves, they don't practice polygamy and they adopt with great ease the customs of their country of immigration. In my view they are a thousand times more preferable than the Turkish mahometans. 
Dollero's statement $(1919,412)$ is made with reference to the 3,000 Muslims he estimated resided in Cuba at the end of the 1910s, leading us to trace both the ways in which such immigrants arrived in Cuba, and how these "antiquated Eurocentric discourses" (Scherer 1998) have persisted into contemporary immigration histories in Cuba.

\section{a) A Brief History of (Muslim?) Arab Immigration}

The first historical record of a "Muslim immigrant's" presence in Cuba derives from the Church records of the Parroquia Mayor de la Habana, which documents the baptism of an adult male in 1593, who took the name Juan de la Cruz upon his conversion to Christianity. Over forty Muslim slaves from across West Africa, North Africa and the Middle East were then recorded as having arrived in Cuba three years later on the Spanish boat, San Agustín, with a list of these slaves' names and places of origin (West and North Africa) presented by Menéndez-Paredes (1999, 24, who numbers the Muslim slaves as 45) and Gomez (2005, 32, whose estimate is 44). However, while these slaves' names are "either clearly or conjecturally" identifiable as Muslim (ibid), ${ }^{7}$ the history of migration from the Middle East and North Africa, and indeed elsewhere, has required different levels of religious concealment for numerous purposes.

Recognising Muslim slaves' arrival from North Africa in turn draws us briefly to the significance of Spain, and especially the Canary Islands as a bridge between the North of Africa and the Americas. Hence, although ignored (or excluded) by Fajardo-Spínola $(1982,8)$ in his discussion of immigrant groups in the Canaries, Arabs were resident in the Canary Islands from the 1500s, with 865 individuals having been identified as Muslims in the Canary Islands Inquisition of 1595, including both free and slave men and women (Anaya-Hernández 1986, 37), many of whom were prosecuted for the "crime" of practicing Islam (Ronquillo-Rubio 1991, 231). If Arabs in Cuba have been denominated as "the most assimilatable" of immigrants, the opposite approach developed in the Canaries, whether Muslims had arrived through voluntary or involuntary migration from West and North Africa. Ultimately, as Anaya-Hernández notes, Muslims in the Canaries were declared to be "the most inassimilatable" of migrants (1986, 38, my emphasis).

Indeed, Spain's unequivocal rejection of Islam and Muslims, in part due to fears of conversions to Islam in its "dominions" (Bristol 2007, 68), led both to the development of Spanish Inquisitorial laws (including Spanish royal decrees issued throughout the $16^{\text {th }}$ Century) which explicitly prohibited the transportation of Muslims or "moors" to "the New World," and to the consequent 
development of mechanisms by which such laws could be by-passed by slave-traders, Cuban immigration officers and migrants alike. Indeed, Guanche argues that Jewish immigrants were present on all boats travelling to Cuba from Spain throughout the $17^{\text {th }}$ Century, and that they gained access to "the New World" by officially declaring their conversion to Christianity (1999, 18). Guanche here draws on Ortiz, who (as noted above) dedicated a significant proportion of his discussion in Los factores humanos to addressing the arrival of Jews since Columbus' journey, and even proposed that "I might remark in passing that Bellester, Aguiló, and Velosa were probably of Jewish origin, as was, in the opinion of many, Christopher Columbus" (Ortiz Counterpoint, 265).

Whilst Guanche ignores Muslim immigration to Cuba throughout this period, again following in Ortiz's footsteps, a similar strategy of the "apparent negation of the Islamic creed" could also have been used by Muslims travelling to "the Americas" in order to hide their "real ethnic identity as "hispano musulmanes"' (as suggested in passing by Menéndez-Paredes 1999, my translation). More directly, Grillo-Candales recognises that Arab immigrants used bribes "to hispanise their names to get around the Spanish royal decree forbidding the arrival of Muslims [in the New World]" $(1998,19)$. Claims to conversion and the hispanisation of names, ${ }^{8}$ reflecting a strategic decision to distance the migrant self from Islam, evidently has long-lasting implications for investigations into this area: the names given by and for migrants arriving in Cuba cannot be utilised as markers of religious identity. Given analysts' reliance on the self-reporting of names in port lists and Cuban baptism and marriage Registers throughout this period, the conclusion that Christians predominated migration flows from the Middle East and North Africa is unsurprising. The limitations of Cuban analysts' almost total reliance upon baptism and marriage registries, and the presence of "Christian Arab" names in these sources (i.e. Charon 1992, 36), are accentuated even further by Menéndez-Paredes' brief recognition that children whose fathers were Muslim and mothers were Catholic were registered in early Cuban censuses as Christian (1999:59).

\section{b) Re-citing Religious Identity and Persecution}

Just as Islam was rendered invisible by immigrants travelling to the New World between the $16^{\text {th }}$ and the late- $19^{\text {th }}$ century, this trend for religious repress-entation arguably continued from the 1870s onwards, when the mass arrival of Arab immigrants accelerated. Although MenéndezParedes recognises in passing that Muslim Arabs' existence in Cuba 'became less visible than it probably was in reality, due to the [groups'] members having to hide their real identity to survive in the colonial society" (2001, 28-29), no detailed analysis has explored how, why and to what 
effect Muslim Arab migrants should have hidden or marginalised their religious identity throughout different periods of Cuba's history.

During the final decades of the Ottoman Empire (1850s to early-1900s), it is widely recognised that "Arab" migrants (often referred to in official records as Turcos and Otomanos - Turks and Ottomans $)^{9}$ often left their region of origin with the intention of travelling to the "Americas" in search of a "better life" (Menéndez-Paredes 1999). Between the 1850s and 1870s, migrants from Greater Syria (Lebanon, Syria and Palestine) tended to transit through Cuba en route to the United States, while approximately 2,000 "Arabs" established small businesses in the island between 1870 and 1900 (ibid). For many of these migrants, socio-political and religious persecution was presented as a prompting factor behind their departure from the MENA region, with the mainstream assumption being that most Arab migrants arriving in Cuba were Christians fleeing Ottoman violence.

However, as noted by Suleiman with reference to Arab immigration to the Americas as a whole,

While the Lebanese Christians (who constitute the overwhelming majority of early Arab arrivals in the US) partly employ religious persecution and the lack of political and civil freedom as the main causes of their emigration from an oppressive Ottoman regime, most, if not all, scholars argue that the most important reason for emigration was economic necessity and personal advancement.

1995, 68, my emphasis

Despite asserting that "most, if not all, scholars" recognise the economic motivations of Arab migration to the Americas (ranging from the economic problems in Mount Lebanon in the mid1800 s resulting from the opening of the Suez Canal, changing of commercial routes and the substitution of Lebanese silk with Japanese silk), Suleiman equally notes that religious persecution was systematically employed by Lebanese Christians, and that "Christian Maronites especially cite the 1860 disturbances and massacres as a main factor for their exodus" $(69$, my emphasis). It is this citation and recitation of religious persecution which permeates much Cuban work on Arab immigration, and helps us understand the strategic representation of the Arab migrant self as a Christian Self, rather than an Arab Muslim Other (also see Fiddian-Qasmiyeh 2014). In this framework, the Ottoman Empire is associated with oppressive Islam, violence and persecution, while Arab migrants, whether "in reality" belonging to the Muslim or Christian faith, 
project themselves as Christian victims and forced migrants in search of a better life, in order to maximise a positive reception from their host state.

In contrast, in the context of the "American society where assimilation into a Eurocentric cultural orientation was practically mandatory," the strategy of choosing "the least offensive" national identity label at one point led to "Maronite Syrians" in the US, for instance, deciding to call themselves "Syrian-Lebanese," thereby eliding their religious identity through a more neutral national typology (Suleiman 1995, 80-81).

\section{c) Re-covering Islam?}

Given the absence of literature focusing on the experiences of Muslim Arabs in Cuba, it is perhaps surprising to note that by 1916, of the 9,000 to 10,000 "Arabs" living in Cuba, Menéndez-Paredes estimates in passing that a third to a quarter of these were Muslim (interview, Havana, 3 November 2006). Although this is itself a significant proportion, it may reasonably be assumed to be an underestimate in light of the abovementioned factors prompting a concealment of religious identity.

Such population estimates are particularly pertinent when we compare the total absence of nonCuban analyses of Arab migration with the high degree of both Cuban and non-Cuban academic interest in Chinese migrants, who were calculated to number 10,300 according to the 1919 Census. By the time of the 1931 Census, ${ }^{10} 24,647$ "Chinese" were registered as resident in the island, ${ }^{11}$ while the colonia árabe (the "Arab colony"), including immigrants and their descendants, was calculated to surpass 35,000 (Charon 1992). ${ }^{12}$ By 1943 López indicates that "the total Chinese population dropped to 15,822 , and by 1953 to 11,834 " $(2009,181)$, while the Arab community reportedly continued to increase. Given the numerical comparability between Chinese and Arab migrants in the island before the Cuban Revolution, it is firstly notable, as indicated above, that so much international attention should have been given to Chinese-Cubans in contrast with the absence of non-Cuban analyses of Arab migration; and it is secondly significant that the 1959 Revolution should officially celebrate Chinese migration as one of the four principal components of Cuban identity, whilst ignoring the Arab component whose demographic presence appears to be equal if not higher.

As suggested above, one reason for this post-Revolutionary national(ist) focus on the Chinese 'component' of Cuban national identity may be related to the exploitation, violence and high mortality rates experienced by the approximately 150,000 Chinese workers ('coolies") who 
arrived between 1848 and 1874 (Baltar-Rodríguez 1997) to replace African slave labour following abolition, and their subsequent revolt to join the independence struggle; despite the demographic composition documented in the early-1900s, the physical suffering historically underpinning their contribution to the Cuban nation is recognised through monuments, commemorations, and identificatory claims: "Even today, Cubans describe their blood as Spanish, African, and Chinese, in that order" (Benton 2010, 159).

Nonetheless, despite official marginalisation, brief references to Muslim Arab migrants' experiences, and the diversity of Muslim religious communities in Cuba prior to the Revolution can be discerned in published and unpublished accounts associated with the Unión Árabe de Cuba (UAC). Hence, Munir-Selman's undated report located in the UAC's library documents the life of Abdul-Latif Esmein (known in Cuba as "Salvador"), who was the religious leader and spiritual guide of the Shi'ite community in the city of Cardenas (Matanzas Province) between 1930 and 1955. In the UAC's publication El Árabe, González and López (1997) present an interview with Hadhem Muhammad Madlum, who was born in Lebanon in 1895, was renamed "Jacinto" upon his arrival in Cuba in 1925 and was aged 100 at the time of interview; in the interview, Jacinto reflects on his experiences in Cuba, noting that "I am Muslim, I have my misbeja ${ }^{13}$ [prayerbeads] and I pray at the burials of those Muslims who die [in Cuba]." Poignantly, and reflecting the natural decrease in the Muslim Arab community in Cuba, the authors report that "when asked who will pray for him when he dies, he says 'I have recorded, on a tape with my own voice, the Quranic verses in Arabic so that they can play it [the tape] before they close the grave"'. A final example emerges in an interview with the head of the UAC's Cultural Commission, Maria Deriche, who briefly notes that her father originated from Palestine and "was a Muslim all his life". ${ }^{14}$ Whilst cursory in nature, these individual and familial accounts of Sunni and Shi'ia Arabs around the island suggest the historical existence, experiences and heterogeneity of Muslim Arabs in Cuba, and prompt the need for further empirical research into this under-researched population; with the passing of time, the collection of first generation Muslim Arab migrants' life histories is becoming, simultaneously, increasingly urgent and unfeasible.

To an extent, such examples support the research completed by Morales-Mesa of the Asociación Islámica de Cuba (Cuba's Islamic Association) who recognises that Arab "Muslims also arrived [in the $19^{\text {th }}$ and $20^{\text {th }}$ Centuries] who undertook their religious practices on an individual basis" whilst arguing that "others converted to Catholicism and very few taught their traditional Islamic 
practices to their descendents" (2002, 96, emphasis added). ${ }^{15}$ The individualised nature of religious practice, and the limited transmission to the younger generation was asserted more stringently by Menéndez-Paredes in our interview, who stated that "the Islam that is practised today in Cuba has nothing to do with the presence of Muslim immigrants in the $19^{\text {th }}$ Century or $20^{\text {th }}$ Century," further asserting that "there was zero transmission between the generations regarding language or religion" and, moreover, that "I don't know of even one case of an Arab immigrant's child practising Islam" (interview, Havana, 3 November 2006). Despite such claims, however, a small number of such instances have been documented to date (see above), and, indeed, even if Menéndez-Paredes is correct that second generation Arab-Cubans did not practice Islam, third generation Arab-Cubans are asserting a renewed interest in their grandparents' religion: the case of the UAC's Maria Deriche suggests this trend, since although she herself is not Muslim, her granddaughter considers herself to be Muslim. ${ }^{16}$

Despite an absence of systematic academic interest in Muslim Arabs in Cuba, Islamic inscriptions remain centrally located in contemporary Havana, and are readily identifiable to those interested in tracing the roots and routes of Arab-Cuban communities, and making a space and a place for Islam within Cuban and non-Cuban accounts of this history of migration. Although Qur'anic inscriptions are absent from the "Arab neighbourhood" of Monte in Havana (where most research has been conducted), a prime example is visible in the patio of a house located on the centrally located $23^{\text {rd }}$ Street in Havana (plate 1), whose entrance is adorned with ceramics which document the religious convictions of the pre-Revolutionary owners of this building, declaring "Walā ghālib ilā Allah": "There is no conqueror but Allah".

\section{$>>$ INSERT FIG 1}

Such inscriptions (which can also be identified, for instance, in Esmein's town of Cardenas), in addition to the labelling of geographical and topological features across the island require further analysis: for instance, it is necessary to investigate the history of naming the Cueva de los Musulmanes (the "Cave of the Muslims") and the Sendero de los Musulmanes (the "Path of the Muslims") in Varadero, and the Playa de los Musulmanes (the "Beach of the Muslims") in Esmein's province of Matanzas, and to establish whose absence (following de Saussure) is denoted by these abstract and tangible "signs" alike. 
Establishing by whom, when and why these geographical features were associated with"Muslims," and when and why the eponymous Muslims themselves were absented from Cuba's socio-political landscape, is particularly significant given that religious identifiers were entirely absent from the titles and stated purposes of the dozens of social, political and philanthropic organisations which emerged between the early-1900s and the mid-1950s, including the Oriental Union (1904), the Syrian Advancement Society (1918), the Palestinian Arab Society (1919) and the Lebanese Society (1920): none of the thirty "Arab" associations registered by the Cuban state during the 1900s had either an implicit or explicit connection with Islam. ${ }^{17}$ In direct contrast, the vast array of Jewish organisations established at the time specifically drew upon and highlighted religious identity and practice: for instance, "Hebrew Religious Community of Cuba", “Adath Israel Hebrew Religious Community of Cuba”, "United Hebrew Religious Society" and "United Hebrew Congregation Temple of Beth Israel".

Indeed, with comparatively few Jews living in Cuba before the Revolution (estimated to number approximately 15,000 by the 1950s - Departamento de Estudios Socioreligiosos 1998), the centrality, and public visibility given to religion in such Jewish/Hebrew associations is notable, as is the existence of four Jewish schools at this time (no Islamic schools existed), and the subsequent wealth of Cuban (ie Sánchez-Porro 1996; López-Levy 2003) and non-Cuban (ie S. Kaplan et al. 1990; D. Kaplan 2000; Levine 1993) academic interest in Cuban-Jews. This leads us to contrast the discursive and institutional space available for the Jewish religion before and after the Revolution, with the continued concealment of Islam in contemporary Cuba.

\section{d) Post-Colonial Demographies, Conmemorations and Arab Spaces}

Following the Cuban Revolution, major socio-political transformations took place in the island, including as a result of the nationalization laws first introduced in 1960-1961. Although many Arab and non-Arab immigrants and their descendants left after the 1959 Revolution, in the 2000s it is estimated that 50,000 Arab-Cubans (first generation immigrants and their descendents) continued to live in Cuba. In contrast, 1,200 and 1,500 Cuban-Jews were estimated to reside in Cuba in 1992 and 1998 respectively (Departamento de Estudios Socioreligiosos 1998, 64). With such a significant difference in the demography of these groups, it is notable that although there is no historical record of a functioning mosque having ever existed in Cuba, five synagogues, a kosher butchery and two Jewish cemeteries remain available for the small contemporary CubanJewish community (ibid). It is equally notable that the University of Havana's Department of Socioreligious Studies explicitly documents Judaism's contemporary role in Cuba (alongside 
Catholicism, Protestantism, "African religions", and "Spiritism") in its "Religious Panorama of Cuba" (64); furthermore, the Woodrow Wilson Centre's workshop report on the impacts of "the constant migratory streams" on the development of religions in Cuba indicates that "The constant interplay of belief systems and practices has resulted in the emergence of particularly Cuban forms of Catholicism, Protestantism, Judaism and Spiritism" (Crahan 2003, 37-54, emphasis added). In contrast, neither make any reference to Islam either in the past or present of the island, although the Department of Socioreligious Studies' Morales-Mesa separately recognises the existence of Islam in Cuba in two unpublished pieces $(1999,2000)$ and one published piece (2002).

If Ortiz's interest in the Chinese contribution to Cuban identity, and that of analysts writing after him, can be related to the physical suffering experienced by Chinese semi-slaves (as suggested above), Ortiz's attention to the presence and influence of Jewish migrants may in turn be related to the historical events taking place in Europe at the time of Ortiz's most influencial work regarding the 'human factors' underpinning cubanness and cubanity. With Cuba being one of the last countries to continue accepting Jewish refugees in the $1940 \mathrm{~s},{ }^{18}$ at the time of the Second World War Ortiz vocally presented an anti-racist, anti-fascist agenda, denouncing Hitler's racial strategies ([1942] 1993, 24) and the expulsion and extermination of the Jews in numerous fora, including through a "memorable lecture at the Hebrew Association in Havana" (del Rosario Diaz $2005,58)$ and in publications such as Los factores $(1939,18)$. Given that post-Revolutionary accounts of migration and nation-building explicitly draw upon Ortiz's work and implicit racial/ethinic and religious hierarchies, his numerous references to Jews, Judaism and Judaists in his oevre arguably provide the foundations for the academic and political space available to document and celebrate the existence and legacy of Jewish migrants to Cuba.

Indeed, both Chinese and Jewish immigration to Cuba are actively commemorated by the Cuban government, including through a major government-sponsored "revival" and "restoration" of Havana's Chinatown since 2006 (López 2009, 192), and a “commemorative coin" marked with the Star of David celebrating "the work which the Jews contributed to the grandness of the city [of Havana]" (Calzada 1997, 4). Notably, however, no similar governmental commemoration or recognition has been offered to Muslim Arabs. Furthermore, while the Cuban state has permitted the creation of multiple spaces for Jewish-Cubans to practise their religion and transmit a religious education to the younger generation (López-Levy 2003), and has celebrated the Chinese "saint" Sanfancón (Scherer 1998), the Cuban state has prevented similar attempts to create 
"popular" Muslim spaces in the island, reportedly rejecting offers made by "several embassies, led by the Iranian and Saudi Arabian missions... to build a mosque in Havana" (US DoS 2009). ${ }^{19}$

A number of Muslim Middle Eastern students interviewed as part of the broader research project referred to above suggested that the government's reluctance was motivated by a fear, which perhaps resonates with Spanish Inquisitorial views outlined above, that conversions to Islam might occur amongst the Cuban population. Indeed, whilst unrecognised by the majority of Cuban and non-Cuban audiences alike, such conversions have been taking place since (at least) 1992, when Cuba was formally recategorised as "secular" rather than a "Marxist Leninist" state, allowing a revitalisation of religious identity and practice across the island (Morales-Mesa 2002, 94). However, although Jewish missions have visited Cuba from the United States and elsewhere since this time, and while conversions to Judaism "from outside" have been documented by Kaplan (2000) and López-Levy (2003), similar visits by non-Cuban Muslims,${ }^{20}$ and the prospect of conversions to Islam have reportedly led to restrictive official state interventions. ${ }^{21}$

Despite the continued invisibility of Muslim Arabs, a small number of "Arab" spaces in contemporary Havana are nonetheless of interest to analysts of Arab migration to Cuba. Firstly, the abovementioned Monte neighbourhood is directly associated with the Arabs who settled in Havana during the late- $19^{\text {th }}$ and early- $20^{\text {th }}$ Centuries; however, unlike Havana's Chinatown, no state support has been forthcoming to restore the area. Those Cuban-funded restoration projects which have taken place have systematically been monopolised by the Office of the Historiador de la Ciudad, which has selected key locations worthy of investment. The prime "Arab" example of this was the Historiador's establishment, in 1983, and more recent refurbishment of the Museo Casa de los Árabes, a state-run museum in the core of the tourist area of Old Havana. Whilst heralded by the Cuban state, however, neither the building selected in 1983, nor the street/area in which the museum is located, are historically related to "Arab" migration. Furthermore, although the Casa de los Árabes is the location of Cuba's only so-called "mosque," which was established by the state in the 1990s and may be considered to be an officially endorsed "Muslim religious space", it is, firstly, only a small "prayer-room" (muSalla) rather than a mosque (masjid), and is typically conceptualised by Muslim residents as "a tourist mosque" for Sunni diplomats and Muslim tourists visiting Cuba (also see Fiddian-Qasmiyeh, 2010).

The second "Arab" space is the Union Árabe de Cuba, the institutional core of the "Arab" community in Havana, which is equally centrally and strategically located, but is also not 
historically an "Arab" building or part of an "Arab" neighbourhood. Indeed, the property was originally owned by the Union Sionista de Cuba (the Cuban Zionist Union), which was reportedly shut down by the Cuban state and handed over to the precursor of the Arab Union in 1978 (López-Levy 2003, 83). Nonetheless, the UAC has increasingly conducted research about Arab migration to the island, and has itself invested in Monte, including by creating a "Memorial to Arab Immigrants" in the neighbourhood in 1998 (El Árabe 1998). Despite a minority of UAC reports recognising Muslims' historical presence in Cuba, and despite a small number of its staff referring to Islam in our interviews, as a whole the UAC continues to reproduce the official stance regarding Arab migration to Cuba, effectively equating Arabs with Maronite Christians.

\section{Conclusion}

Drawing this piece to a close, I argue that there is a particular urgency to make a space and a place for Islam within Cuban and non-Cuban accounts of migration, and post-revolutionary Cuban national identity alike, beginning with researchers retracing both the presence and absence of Muslims in Cuba's history and present. By centralising references which have until now been relegated to margins and footnotes, this article has presented an alternative history to that which prevails in official "archives of knowledge" pertaining to Arab migration to Cuba. Tracing the accumulative processes of repress-entation which have characterised the official celebration of "Arab migrants" as "the most assimilatable" of all immigrant groups, I have argued that this assertion's success is itself dependent upon the apriori erasure of Muslim Arabs from Cuba's hybrid "national identity."

As is often the case, the arrival of Arab immigrants to Cuba has been analysed according to Cuban national priorities. Hence, the ever-expanding number of Cuban analyses of Arab migration systematically reflects an official Cuban political commitment which derives in part from Cuba's post-colonial and revolutionary experience: these studies pay homage to the role played by different migrant communities in creating "Cuban national identity," asserting, rather than exploring, processes of successful assimilation and integration.

However, Cuban academic and institutional accounts of transculturation and post-revolutionary cultural and racial hybridity have simultaneously been characterised by what I refer to as systems of religious footnoting, through which particular groups of migrants have been rendered invisible. Bearing the legacy of Cuba's colonial past, throughout different periods of history, Islamic identity and practice have been strategically concealed by members of immigrant and "host" 
populations alike through a variety of mechanisms, ranging from the hispanisation of migrants' names and the "recitation" of claims of religious persecution, to a distinctive process of accumulative erasure via a failure to identify or analyse the presence and experiences of Muslim Arabs in the island. In effect, Muslim immigration both before and after the Cuban Revolution has been overshadowed by a systematic focus on Christian Arabs, thereby leading to the category "Arab" being practically synonymous with "Christian," with wide-ranging implications for our understanding of Cuba's academic and political discourses regarding national identity and both racial and religious hierarchies in the twentieth and twenty first centuries alike. In essence, the continuity of Muslims' marginalisation by Cuban academics and officials today leads us to ask whether Cuba is now ready to revisit the legacy of colonial systems of repress-entation inherited from Spain, and to resist colonial and post-colonial oppositions to Islam.

\section{REFERENCES}

Al-Ahari, M.A. 1999. "The Caribbean and Latin America.” In Islam Outside the Arab World, edited by David Westerlund and Ingvar Svanberg, 443-461. New York: St. Martin's Press.

Almond, I. 2007. The New Orientalists: Postmodern Representation of Islam from Foucault to Baudrillard. London: IB Tauris.

Anaya-Hernández, L.A. 1986. 'Las minorías en la historia de Canarias.' VII Coloquio de Historia Canario-Americana, I, 31-57.

Arias-Castillo, E. n.d. Algunos apuntes para reconocer la influencia del Arte Islámico en Cuba. Simposio Internacional: La Presencia Árabe en Cuba.

Archivo Nacional de Cuba. 1995. Registro de Asociaciones. Havana: Archivo Nacional de Cuba.

El Árabe. 1998. 'Memorial a los Inmigrantes Árabes,' El Árabe No. 51. n.p.

Baltar-Rodríguez, J. 1997. Los chinos de Cuba: Apuntes etnográficos. Havana: Fundación Fernando Ortiz. 
Benton, G. 2010. "China, Cuba, and the Chinese in Cuba. Emigration, international relations, and how they interact." In China and International Relations, edited by Zheng Yongnian, 158-176. London: Routledge.

Bristol, J.C. (2007) Christians, Blasphemers, and Witches: Afro-Mexican Ritual Practice in the Seventeenth Century, Albuquerque: University of New Mexico Press.

Calzada, A. (1997) “La Huella Judía en Cuba.” Opus Habana 1(1): 1-5.

Charon, E. 1992 ‘El asentamiento de emigrantes árabes en Monte (La Habana, Cuba), 18901930.' Awraq 13: 35-68.

Civantos, C. 2006. Between Argentines and Arabs: Argentine orientalism, Arab immigrants, and the writing of identity. New York: SUNY.

Crahan, M. (2003) Cuban diasporas: Their impact on religion, culture and society,' In Religion, Culture and Society: The Case of Cuba, edited by Margaret Crahan, 37-54. Washington:

Woodrow Wilson Centre Reports on the Americas.

Davies, C. 2000. "Fernando Ortiz's Transculturation: the Postcolonial Intellectual and the Politics of Cultural Representation" in Postcolonial Perspectives on the Cultures of Latin America and Lusophone Africa, edited by Robin Fiddian, 141-168. Liverpool: Liverpool University Press.

Departamento de Estudios Socioreligiosos. 1998. Panorama de la Religión en Cuba. La Habana: Ed. Política.

Dollero, A. 1919. Cultura Cubana. Habana: Seoane y Fernández.

Fajardo-Spínola, F. 1982. Extranjeros ante la Inquisición de Canarias en el Siglo XVIII. Gran Canaria: Colección Guagua.

Fiddian-Qasmiyeh, E. 2010. 'Education, Migration and Internationalism: Situating Muslim Middle Eastern and North African students in Cuba.' Journal of North African Studies 15(2):137-155. 
Fiddian-Qasmiyeh, E. 2014. The Ideal Refugees: Gender, Islam and the Sahrawi Politics of Survival. Syracuse: Syracuse University Press.

Fiddian-Qasmiyeh, E. 2015. South-South Educa- tional Migration, Humanitarianism and Development: Views from the Caribbean, North Africa and the Middle East. Oxford: Routledge.

Foucault, M. 1989. Foucault Live: Interviews 1966-84. New York: Semiotext.

de la Fuente, A. 2001. A Nation for All: Race, Inequality, and Politics in Twentieth-Century Cuba. Chapel Hill: University of North Carolina Press.

Gomez, M.A. (2005) Black crescent: the experience and legacy of African Muslims in the Americas, Cambridge: Cambridge University Press.

González, M. 2003. Los Árabes. La Habana: Ediciones de Ciencias Sociales.

González, M. 1997. 'La inmigración árabe en Cuba: su influencia en nuestra cultura,' El Árabe 45: np.

González, M. and López, R. 1997. 'Jacinto Madlum: Un centenario para una historia,' El Árabe 45: n.p.

Grillo-Candales, L. 1998. 'La Impronta Árabe en el siglo XIX Cubano,' El Árabe 51: n.p.

Grillo-Candales, L. n.d. Mambises Árabes. Unpublished material located in Unión Árabe de Cuba Library.

Guanche, J. 1999. España en la savia de Cuba: Los componentes históricos en el etnos cubano. Habana: Editorial de Ciencias Sociales.

Guanche, J. 2005. Componentes etnicos de la nacion cubana, Ediciones Guarapo, 2nd Edition (CD-ROM).

Jozami, G. (1996) 'The Manifestation of Islam in Argentina,' The Americas, Vol. 53, No. 1, pp. 67-85. 
$\mathrm{Ju}$, A. (2014) "Representations of Chinese-ness in Afro-Cuban hip hop during post-Soviet era Cuba," in Malone, C. and G. Martinez (eds) The Organic Globalizer: Hip-Hop, Political Development and Movement Culture. New York: Bloomsbury Academic. 160-188.

Kaplan, S. Moncarz, R. and Steinberg, J. 1990. 'Jewish Emigrants to Cuba: 1898-1960.' International Migration 28(3): 295-310.

Kaplan, D.E. 2000. 'A Jewish Renaissance in Castro’s Cuba.' Judaism 49(2): 218-36.

Klich, I. and Lesser, J. 1998. Arab and Jewish Immigrants in Latin America: Images and Realities, Oxford: Routledge.

Levine, R. 1993. Tropical Diaspora: The Jewish Experience in Cuba. Florida: University of Florida.

López, K. 2004. “"One Brings Another’: The Formation of Early-Twentieth-Century Chinese Migrant Communities in Cuba," in The Chinese in the Caribbean, edited by Andrew Wilson, 93127. Princeton: Markus Wiener Publishers.

López, K. 2009. 'The Revitalization of Havana's Chinatown: Invoking Chinese Cuban History.' Journal of Chinese Overseas 5: 177-200.

López-Levy, A. "The Jewish Community in Cuba in the 1990s," in Religion, Culture and Society: The Case of Cuba edited by Margaret Crahan, 79-89. Washington: Woodrow Wilson Centre Reports on the Americas.

Menéndez-Paredes, R. 2001. 'La Huella Árabe en Cuba.' Opus Habana 5(1): 26-35

Menéndez-Paredes, R. 1999. Componentes Árabes en la Cultura Cubana. Habana: Editorial Bolaña.

Menéndez-Paredes, R. 1998. 'La Ultima Maronita.' Opus Habana 2(2): 53-55. 
Morales-Mesa, A. 1999. El Islam en Cuba. Habana: Departamento de Estudios Sociorreligiosos (unpublished).

Morales-Mesa, A. 2000. La Comunidad Islámica Cubana. Habana: Departamento de Estudios Sociorreligiosos.

Morales-Mesa, A. 2002. “El Islam en la Actualidad Cubana.” Revista Académica para el Estudio de las Religiones 4: 93-102.

Munir-Selman, R. n.d. “Abdul-Latif Esmein "Salvador”. Unpublished material located in Unión Árabe de Cuba Library.

Nejme-Franco, G.S.. n.d. Mártires de la Revolución de Origen Árabe. Unpublished material located in Unión Árabe de Cuba Library.

Núñez Jiménez, A. (1984) Cuba: Cultura, estado y revolucion. Mexico City: Presencia Latino Americana.

Ortiz, F. 1964. 'Cubanidad y Cubanía.' Islas 6(2): 91-96.

Ortiz, F. [1947] 1995 Cuban Counterpoint: Tobacco and Sugar. Introduction by B. Malinowski, with a new introduction by F. Coronil. Durham and London: Duke University Press.

Ortiz, F. [1942] 1993. "El mutuo descubrimiento de dos mundos" reprinted in Etnia y Sociedad by Fernando Ortiz, 21-27. Habana: Editorial de Ciencias Sociales.

Ortiz, F. [1939] 1991. "Los factores humanos de la Cubanidad" reprinted in Estudios Etnosociologicos by Fernando Ortiz, 10-30. Habana: Editorial de Ciencias Sociales.

Ortiz, F. [1913] 1986. "Las supervivencias africanas en Cuba" in Entre Cubanos. Psicologia Tropical by Fernando Ortiz, 86-89. Habana: Editorial de Ciencias Sociales.

Ortiz, F. 1997. "Los Factores Antropológicos" reprinted in El pueblo cubano by Fernando Ortiz, 14-34. Habana: Editorial de Ciencias Sociales. 
Perdomo-Lorenzo, G. 1992. Aproximación al estudio de la inmigración Árabe en Cuba. Habana: Centro de Documentación e Información de la Unión Árabe de Cuba.

Ramírez-Calzadilla, J. (2005) "Religion in the Work of Fernando Ortiz" in Cuban Counterpoints: The Legacy of Fernando Ortiz edited by Mauricio Font and Alfonso Quiroz, 193-205. Lanham: Lexington Books.

Roland, L. K. 2006. 'Tourism and the Negrificación of Cuban Identity.' Transforming Anthropology, 14(2): 151-162.

Ronquillo-Rubio, M. 1991. Los origines de la Inquisición en Canarias: 1488-1526. Las Palmas: Ediciones del Cabildo Insular de Gran Canaria.

del Rosario-Díaz, M. 2005. "Ethnography at the University of Havana" in Cuban Counterpoints: The Legacy of Fernando Ortiz edited by Mauricio Font and Alfonso Quiroz, 55-62. Lanham: Lexington Books.

Sánchez-Porro, R. 1996. 'Tradición y modernidad: Los judíos en La Habana.' Cuadernos de Historia Contemporánea 18:175-189.

Sánchez-Porro, R. 1994. Communidades Árabes de Cuba. Unpublished manuscript. Habana: CEAMO.

Scherer, F. 1998. Sanfancón: Orientalism, Confucianism and the Construction of Chineseness in Cuba, 1847-1997. CERLAC/CRP Working Paper

Suleiman, M. 1995. 'Arab Immigration to America. 1880-1940.' AWRAQ: Estudios sobre el mundo árabe islámico contemporáneo 16: 67-85.

United States Department of State, 2009. International Religious Freedom Report: Cuba. Available at http://www.state.gov/g/drl/irf/rpt/index.htm, last accessed 20/06/2010.

\footnotetext{
${ }^{1}$ All translations from Spanish publications and interviews are my own.

${ }^{2}$ I thank Y.M. Qasmiyeh for his insights regarding this conceptualisation.
} 


\footnotetext{
${ }^{3}$ The "four" races are sometimes reduced to three core groups "and others": for instance, his courses at the University of Havana in the 1940s on "Races and historical cultures that have formed the Cuban people" focused on "Cultural factors of Indians, Africans, Europeans and others: the phenomenon of their transculturation" (in del Rosario-Diaz 2005, 56, emphasis added). Like Ortiz, more recent research by Cuban academics oscillates between identifying four or three foundational races - hence, directly referring to Ortiz's work, Núñez refers to the "the various racial fusions... when Indians, Spaniards and Africans began to create the racial blend that defines us" (2).

${ }^{4}$ My concern with "religion" clearly reflects my personal and academic interests in the context of the contemporary geo-political situation, just as $20^{\text {th }}$ century analysts' focus on "race" reflected the realities and politico-ethical challenges of that era. I thank the reviewer for highlighting this point.

${ }^{5}$ Thanks are due to the anonymous reviewers of this piece for their insights regarding this matter.

${ }^{6}$ In this context, "Syrians" refers to individuals originating from Greater Syria, encompassing the area currently denominated as the Levant (including Palestinians, Lebanese and Syrians).

${ }^{7}$ Gómez primarily focuses on 'possible' African Muslims, but also identifies five possible 'Arab' Muslims originating from the Ottoman heartland and Morocco; however, he does not appear to consider two individuals arriving from 'Arjel' (Algiers/Algeria) and one from Tunez (Tunis/Tunisia) as 'possible Muslims' (33). Interestingly, Morales-Mesa recognises that slaves arriving in Cuba included "Muslims, Arabs and Berbers", thereby drawing an implicit typological separation between these three groups, rather than analysing the potential overlaps between religious and ethnic identies $(2002,94)$.

${ }^{8}$ Regarding Chinese immigration to Cuba, López notes that Chinese associations in the early-20th Century "gave new Chinese migrants their Western names" $(2009,179)$, indicating that such processes of hispanisation have continued across time and space.

${ }^{9}$ Broader methodological difficulties arise, partly, from the applicability of the category "immigrant" only to those travelling in third class, and due to the different national and ethnic labels used in registers at different points of the $19^{\text {th }}$ and $20^{\text {th }}$ Centuries (Charon 1992, 40). Such labels shifted over time: the term "Arabia" emerged in the early-20 ${ }^{\text {th }}$ Century to encompass Lebanon, Syria and Palestine (Menéndez-Paredes 1999), and the categories "Iraqi" and "Libyan" were used from the 1930s (Charon 1992).

${ }^{10}$ In 1940, the new Cuban Constitution facilitated family reunification, increase both Chinese and Arab immigration to the island (López 2009, 180).

${ }^{11}$ At the risk of "footnoting" a "parenthetic minority," it is notable that Al-Ahari proposes that by 1959, the majority of Muslims in Cuba were Chinese Muslims $(1999,447)$. Whilst requiring further examination, this claim raises questions surrounding the displacement of Islam not only in studies of Arab migration to Cuba, but also within studies of Chinese migration, pushing Scherer and other analysts to consider the significance of non-Confucian Chinese religions, such as Islam, in Chinese-Cuban experiences.

${ }_{12}$ Between 1869 and 1931, 20,565 Arab immigrants are officially recorded as having arrived in Cuba (Menéndez-Paredes 1998, 53). The 1953 Census is the first to have collected the number of Arabs residing in Cuba (Charon 1992, 46), meaning that estimates for the 1930s largely derive from Cuban analysts' extrapolations from the official Registries (quoted in ibid).

${ }^{13}$ The Classical Arabic term is misbaha.

${ }^{14}$ Available at http://www.cubasolidarity.com/aboutcuba/topics/race/0311cubanarabs.htm, last accessed on 17 June 2010.

${ }^{15}$ In contrast, Ortiz argued, with reference to "African" religions, that "the gods do not spontaneously die" in "contexts of religious transculturation" (1963, 243, author's translation); however, whilst recognising the "resistance" of Afro-Cuban religious identity and practice, there is no reference to the survival of the religion of the "Levantines" or "Turks".

${ }^{16}$ Available at http://www.cubasolidarity.com/aboutcuba/topics/race/0311 cubanarabs.htm, last accessed on 17 June 2010.

${ }^{17}$ Author's compilation of Associations Registered by the Cuban state during the 1900s (Archivo Nacional de Cuba, 1995).

${ }^{18} \mathrm{I}$ am grateful to the reviewer for highlighting this point.

${ }^{19}$ However, the small Shi'a Al-Ma'sumin Islamic Centre has reportedly been built with funding from the Iranian government (US DOS 2009).

${ }^{20}$ Morales-Mesa refers to the support provided by Muslim communities from the Arab Emirates, Qatar, Canada, Panama and Brazil (p. 99).
} 
${ }^{21}$ Although a small community, my research in 2006 confirms that a number of Cubans unrelated to the earlier waves of Arab migration have indeed converted to Islam, at times through interactions with Muslim students and diplomats (Fiddian-Qasmiyeh 2010c). 